\title{
The FRAGILOME project, a strategy for the discovery of new gene biomarkers in cancer
}

\author{
Manfred Schwab \\ From 16th International Charles Heidelberger Symposium on Cancer Research \\ Coimbra, Portugal. 26-28 September 2010
}

Chromosomal instability is a common finding in all malignant tumor types. Structural chromosome aberrations are frequently caused by non-random DNA damage at locus-specific regions of the genome, known as common fragile sites (cFS). DNA at cFS can suffer double-strand breaks when cells are grown under conditions of replication stress. cFS are considered to be present in all individuals and represent a normal component of chromosomal structure. The human genome contains approximately $120 \mathrm{cFS}$ regions that have been cytogenetically mapped to specific sites distributed over all chromosomes. Instability at $\mathrm{cFS}$ thought to be a critical initiating event in the generation of genomic DNA damage during tumor development. One prototypic example for the role of cFS activation is oncogene amplification, where multiple breakage-fusion-bridge cycles (BFB cycles) depart from an activated cFS with the consequence of increased gene copy numbers, like for instance the amplified $M Y C N$ gene in the pediatric cancer neuroblastoma.

We have initiated a project known by the acronym FRAGILOME, which is positioned within the Human Cancer Genome endeavour and has its major goal in (i) mapping and identifiying of the full repertoire of cFS genes in the human genome, (ii) determining the genetic material damaged upon activation and unfaithful repair of $\mathrm{cFS}$, and (iii) defining the role that cFS genes may have in human tumorigenesis [1,2].

Mapping and identifying cFS genes is being done by multicolor chromosomal fluorescence in situ hybridisation (FISH). Determining the genetic material damaged as the result of cFS activation is done by a designer high density CGH array (FRA-CGH chip) targeting sequences of identified cFS genes.

Correspondence: m.schwab@dkfz-heidelberg.de

German Cancer Research Center (DKFZ), Heidelberg, Germany
The preferential cFS activation at early stages of carcinogenesis makes these genomic regions likely targets for identifying critical alterations of genetic material in human cancers and for discovering new DNA biomarkers for clinical use.

Published: 24 September 2010

\section{References}

1. Fragilome: Determining the Role of Fragile Sites in Human Disease. In Special Issue "FRAGILOME - Common Fragile Sites, Genomic Instability, and Cancer". Cancer Lett Schwab M 2006, 232:1-122.

2. Savelyeva L, Sagulenko E, Schmitt JG, Schwab M: The neurobeachin gene spans the common fragile site FRA13A. Hum Genet 2006, 118:551-558.

doi:10.1016/j.canlet.2005.07.044

Cite this article as: Schwab: The FRAGILOME project, a strategy for the discovery of new gene biomarkers in cancer. BMC Proceedings 2010 4(Suppl 2):019.
Submit your next manuscript to BioMed Central and take full advantage of:

- Convenient online submission

- Thorough peer review

- No space constraints or color figure charges

- Immediate publication on acceptance

- Inclusion in PubMed, CAS, Scopus and Google Scholar

- Research which is freely available for redistribution

Submit your manuscript at www.biomedcentral.com/submit
C Biomed Central 